\title{
A RORSCHACH-PRÓBA HAZAI ÚTJA
}

\section{CSÁSZÁR-NAGY NOÉMI}

\author{
Nemzeti Közszolgálati Egyetem \\ Pszichoszomatikus Ambulancia \\ E-mail: noemi.csaszar@areus.hu
}

Beérkezett: 2020. február 28. - Elfogadva: 2020. február 29.

Célkitúzés: A tanulmány a Rorschach projektív személyiségvizsgálat meghonosodásának, elterjedésének és a - fơként klinikai területeken való - alkalmazásának útját kívánja nyomon követni. Mindmáig nincs rendezett és hiteles történeti feldolgozása a tesztnek a hazai alkalmazott lélektani fejlödés kereteibe helyezve. Ezt pótolja jelen munkánk.

Módszer: Történeti és alkalmazásfejlödési adatgyüjtés forrásmunkákból merítve, valamint idôrendben követett publikációs aktivitás tükrében öt idörendi-folyamati fejlődési szakasz különíthetô el. Legmarkánsabb fejlödési ugrás a Közös Rorschach-próba bevezetése és képzése volt, valamint a nemzetközi szintü Rorschachmegújulásban hazánkban is bevezetés alatt álló R-PAS, a teljesítményelvü Rorschach-teszt.

Eredmények: A tanulmány követhetốvé teszi a hazai betelepitésben és meghonositásban a Szondi-iskola munkatársainak szerepét. A klinikai pszichológiai gyakorlatban Mérei Ferenc és Szakács Ferenc jelentôségét, a Közös Rorschach hazai kultúrában pedig Bagdy Emóke tevékenységének szerepét.

Konklúzió: A teszt megújulva tovább él, módszertani eljárásaiban követve a változó pszichológiai szemléletnek a gyakorlati munkában érvényesülô kihatásait. A tesztkövetelmények (validitás, megbizhatóság, standardok megújitása stb.) azonban idôt átíveló módon állandóak.

Kulcsszavak: Rorschach-teszt, Közös Rorschach Vizsgálat (KRV), magyar teszttörténeti adatok 


\section{Kezdetek: a Rorschach-teszt meghonosodása a hazai pszichodiagnosztikában}

Hogyan került be Magyarországra a teszt? A meghonosodás útja jól követhetô, a behozó személyt titok fedi. Sokirányú keresés nyomán sem találtunk egyértelmú bizonyítékokat. Az emlékezók és a keresésben kompetens segítók: ${ }^{1}$ Lányiné Engelmayer Ágnes, Pléh Csaba, Illyés Mária (Kozmutza Flóra lánya), Mérei Zsuzsa, Szakács Ferenc, Gyöngyösiné Kiss Enikô és Bagdy Emôke személyes közlései, továbbá K. Horváth Zsolt (2011) Mérei Ferencrôl írt doktori értékezésének gazdag történeti interjú elemei, valamint Karl Bürgi-Meyer (1996) svájci Szondi-kutató tanulmányában fellelt említések, Szakács Ferenc (2010, 2019) írásai, Mérei és Szakács Ferenc (1974a, 1974b) egyes könyvei, végül Tarcsay Izabella 1940-ben kiadott Rorschach-tankönyvében fellelhetô adatok bizonyultak érdemi történeti forrásnak.

A keresés szálai két irányba vezettek, és végül Mérei Ferenc Rorschach-honosító kutatási és gyakorlati alkalmazási tevékenységében fonódtak össze. A Mérei család nem talált a hagyatékban a teszt behozatalára vonatkozó adatokat. A szakmatörténeti nyomkövetés azonban az ô különleges „honfoglaló” szerepére világított rá. Ez egyrészt a Szondi-laboratóriumban, másrészt a Schnell János által vezetett Állami Gyermekpszichológiai Intézetben bizonyult jelentôsnek. Mindkettôben nagyra értékelték szervezó talentumát és statisztikai tudását. Tudományszervezésben, tervezésben és „a gondolatok megperspektívázásában” (ahogyan ô ezt megnevezte) élenjáró volt. A hazai Rorschach-kultúra elindításában az ô elsô lépéseinek nyomait érhettük tetten. Mindezt az alábbiakkal tudjuk alátámasztani.

Szakmatörténeti tény, hogy 1926-ban Ranschburg Pál (az elsô Magyar Pszichofizikai Laboratórium megteremtője, a Magyar Pszichológiai Társaság megalapítója) visszavonulását követôen a Gyógypedagógiai Pszichológiai Laboratórium kettévált. Egyik ága Schnell János vezetésével először Állami Gyógypedagógiai Intézetté, késôbb Állami Gyermek Pszichológiai Intézetté alakult. Másik ága Magyar Királyi Kórtani és Gyógytani Laboratórium lett. Ezt Klebelsberg Kunó vallás- és közoktatásügyi miniszter utasítására alapították, a gyógypedagógiai tevékenység biológiai, természettudományos, kísérleti, egzakt alapokra helyezése céljából. Ennek vezetôje Szondi Lipót lett, aki 1927-tôl irányította az intézetet. Ebben az évben kapta meg a pszichopatológia és -terápia professzora címet. 1937-ig (ösztöndiagnosztikai tesztjének bemutatásáig) genotróp tárgyválasztási elméletének kidolgozása keretében hatalmas, statisztikailag is megalapozott kutatómunkát folytatott harminc munkatársával, hogy a betegségválasztás genetikai bizonyíthatósága érdekében elméletét specifikus tesztvizsgálattal is alátámaszthatóvá tegye. Harminc munkatársa között volt a késôbb is Szondi-teszttanárként múködô és publikáló néhány kutató és vizsgáló kolléga, így Mérei Ferenc és Mérei Vera (ôket Szondi két apródjának nevezték el), Molnár Imre, Kozmutza Flóra, Sándor Klári és Benedek István.

Karl Bürgi-Meyer (1996) pontos felsorolást ad azokról a munkatársakról, akiket Szondi tanítványaiként megnevezett. Ilyen volt Gleimann Anna, Binét Ágnes, György

Hálás köszönettel tartozom a „segítôknek”, akiknek személyes közlései, emlékei, „nyomozati munkája”, egyéni erôfeszítései nélkül e hazai Rorschach-történet nem jöhetett volna létre. 
Júlia, Kozmutza Flóra, Mérei Ferenc, Mérei Vera, Liebermann Lucy, Tarcsay Izabella. Ôk valamennyien tanították a tesztek használatát, késóbb pedig a hatvanas években megújuló pszichológiai gyakorlatban Rorschach-múhely szervezôdött köréjük. Idesorolható még Noszlopi László, Sándor Klári, Balázs Péter (késôbb a Szondi-teszt elismert tanárai). Noszlopi László (1989) könyvet is írt a Szondi-tesztrôl. Ugyancsak tanítványok voltak Lénárd Ferenc és Kardos Lajos, is akik késôbb egyetemi pszichológiatanárként, professzorként építettek karriert.

Szondi laboratóriumában hangyaszorgalmú munka folyt, amire maga Szondi igen büszke volt. „A laboratórium egy lázasan dolgozó hangyatársadalom” - vallotta (hivatkozza Bürgi-Meyer svájci Szondi-kutató, 1996). Hatalmas volumenú családfakutatás és a családok sok szempontú vizsgálata zajlott. Ennek során a Rorschach-tesztet rendre alkalmazták. Bürgi-Meyer tanulmánya utal rá, hogy Szondi többdimenziós alkatelemzési kvalitatív és kvantitatív rendszert dolgozott ki lelki zavarban szenvedó gyermekek és fiatalok részére. Biológiai mutatók, növekedés, érettség, szomatikus és pszichológiai alkati felépítés, elemzés és mérés, családi kórismék feldolgozása, átfogó öröklésbiológiai és genealógiai analízis során a több héten át folyó vizsgálatokban a pszichológiai vizsgálati eszközök sokaságára támaszkodott, átfogó karakter- és személyiségvizsgálatokat végeztetett. Többek között - állítja Bürgi-Meyer - a Binet-Simon- és Rorschach-teszteket is alkalmazták, majd 1938-tól a Szondi által kidolgozott ösztöndiagnosztika is bevezetésre került. A Rorschach-teszt mindebben úgy tûnik fel, mint egyike a tesztrepertoárnak, az eredet megjelölése nélkül. Mérei Ferenc e vizsgálatokban kezdettôl aktívan és minden bizonnyal alakítóan vett részt. Bagdy Emôke emlékezett arra, hogy az idős Molnár Imre egy pszichológus-érdekvédelmi ülésen anekdotikusan mesélte, milyen zseniális volt a Rorschach-tudásban Gleimann Anna. Ô volt a szakértô, akitôl mindnyájan sokat tanultak, szerinte maga Mérei is. Bagdy Emôke azzal a (nem bizonyítható) feltételezéssel él, hogy eredetileg Gleimann Anna hozta be a tesztet Magyarországra. Bizonyos azonban, hogy az „aranycsapat” kezdte el 1937 után a tesztek tanítását, a Szondi-teszt széles körben való elterjesztését, multiplikátor tanárok képzésével. Ugyanezek a tanárok a Rorschachhal is dolgoztak.

Harkai Schiller Pál egyetemi tanár, aki pályakezdőként még Ranschburg Pál intézetében volt kutató munkatárs, 1936-ban egyetemi tanárként megszervezte a Lélektani Intézetet és a Magyar Pszichológiai Társaság gyakorlati lélektani szakosztályát. Nem meglepó, hogy a körülötte csoportosuló pszichológusoknak nemcsak lehetôvé tette a teszt tanulását, hanem támogatta a rendszeres alkalmazását is (K. Horváth, 2011).

Szondi laboratóriumában szinte elárasztó módon folyt a tesztek tanítása 1937 után 1941-ig, mintha csak a külvilági destrukció nem érhette volna el. Maga Szondi két kurzust vitt hetente, és az orvosok, pszichológusok, gyógypedagógusok, sôt pszichoanalitikusok számára is önálló kiképzô kurzusokban folyt a Szondi- és Rorschach-tesztek oktatása (Bürgi-Meyer, 1996). Ez idố tájt a Rorschachot már-már divatszerúen alkalmazták. 1937. február 20-án került sor például József Attila Rorschach-vizsgálatára is, privát baráti körülmények között. Errôl Kozmutza Flóra számolt be leányának írt emlékezőkönyvében (Illyés Gyuláné, 1987). A befejezetlen tesztvizsgálat feldolgozása évtizedekkel késôbb, Kozmutza Flóra kérésére történt meg (Bagdy, 1992). A teszt sajátos tartalomelemzését a költô identitáskonfliktusának feltárása céljából Garai László végezte el (Garai, 1992). Gyöngyösiné Kiss Enikô Szondi-szakértő szerint a Szondi-teszt 
validálása nagy valószínúséggel a Rorschachhal történt, azonban az bizonyos, hogy Molnár Imre ötszáz iskolás gyermekkel tervezett Rorschach-vizsgálatot. A táblák felszólító jellegére irányuló érdeklődése nyomán olyan kísérletsorozatot indított el, amelyben a szavak affektív színezetét kívánta elemezni. A tervbôl 200 gyermek vizsgálata készült el Gleimann Anna és Dalik Ilona közremúködésével (K. Horváth, 2011, 273).

Mérei ebben az idóben a Schnell János által vezetett Magyar Királyi Gyermeklélektani Intézetben is díjtalan önkéntes munkatárs volt, ahol a gyakorlati pszichológiára összpontosított. Saját kutatási témaként a pályaválasztás optikájából vizsgálta az intelligencia kérdését és hiteles mérésének módjait. Tesztbattériát dolgozott ki a pályaválasztási tanácsadóba kerülő gyermekek általánosintelligencia-vizsgálatára. Sok száz gyermeket bevonó vizsgálatainak alapkoncepcójaként írta le, hogy a képességek felmérésére törekvô, analitikus közelítés nem elegendô. Kifejtette, hogy a személyiség egészének, érzelmi reakcióinak (gátlás, motivációs zavar stb.) és viselkedésének (kontrollképesség, önszabályozás) kereteibe helyezve jósolható be a tényleges teljesítmény (idézi K. Horváth, 2011, 265-267). Mérei 1938-1942 között pályaválasztási privát rendelőben dolgozott. Kun Miklóssal együtt tanácsadót múködtettek (K. Horváth, 2011, 291). Maga Kun Miklós emlékezik K. Horváth Zsoltnak adott interjújában arra, menynyire intuitív és zseniális volt Mérei a rendre alkalmazott Rorschachok kiértékelésében. Elmondta például, miképpen ismert fel egy agydaganatot Mérei a Rorschach-válaszok alapján (K. Horváth, 2011, 58-60). Ismeretes, hogy noha az intuitív elemzést Mérei a saját munkájában alkalmazta, tanítványainak késôbb tiltotta, csak a lejelölt és kiszámított teszt értékelését fogadta el. Schnell János igazgatónak a tesztekhez, speciálisan a Rorschach-teszthez való elfogadó viszonyát jól jelzi egy anekdotikus mozzanat. Szakács Ferenc az idôs Schnell Jánosnál járt egy ízben. Az igazgatói szoba egy szép aktfestményén megakadt a tekintete. Schnell megjegyezte: „Ugye szép? Szebb, mint a Rorschach-képek" (Szakács, szóbeli közlés).

Az egyetlen fontos bizonyíték a teszt magas színvonalú használatára Tarcsay Izabella Rorschach-tankönyve (Tarcsay, 1940), amely a háború évében támogatott magánkiadásként jelent meg. Tarcsay arról tudósít, hogy a teszt alapvetô pszichológiai vizsgálati módszer, amely munkaeszköz a szakember számára. Utal arra, hogy 1935-1940 között a Benedek László professzor által vezetett Budapesti Ideg-Elmeklinika nem csupán alkalmazza a teszt használatát, de kutatásokat is kezdeményez a klinikum területén, elsôsorban a Rorschach- és a Szondi-tesztekkel. Angyal Lajos és Horányi Béla (késôbbi professzorok) nevét említve tájékoztat a tesztekkel folyó kutatásokról. Arról is tudósít, hogy az 1936-ban a Harkai Schiller Pál professzor által megalapított Lélektani Intézetben az igazgató által támogatott tesztgyakorlat folyik, és a kutatások szabad utat kapnak. Megjegyezzük, hogy Tarcsay is a Szondi Lipót által kiemelten felsorolt munkatársak közé tartozott, noha erre, valamint saját munkájának intézményi kereteire semmiféle utalás nem történik. Tarcsay könyvéból láthatjuk, milyen magas színvonalú munka folyhatott ez idôben a magyar ég alatt, elsôsorban a német nyelvterületen kialakuló rorschachozás konvencióit követve. Mérei Ferenc bizonyosan ezt a gyakorlatot tanította és alkalmazta ez idôben. Emellett szól, hogy e könyv képezte késôbb (1964-ben) a megújuló klinikai tesztgyakorlatban a rorschachozás báziskönyvét, amelynek fejlesztésével bontakozhatott ki ismét a tesztgyakorlat. 
Az eddigiek alapján aligha kétséges, hogy a Szondi-laboratóriumban ringott a tesztek bölcsôje, hogy elfogadott volt az intézményekben is a tesztelési gyakorlat, hogy a Gyermeklélektani Intézet is a Szondi-laborban kiképzôdô munkatársakat alkalmazta a kutatások szervezésében és a gyakorlati munkában, és hogy Mérei Ferencnek oroszlánrésze volt a nagy kiterjedésû mintavétellel dolgozó kutatómunka meghonosításában és a tesztek, elsôsorban a Rorschach tanításában. A romló politikai helyzet ellenére a harmincas évektôl kezdve széles körben képviselte, tanította, alkalmazta a tesztet, sốt a felszólító jellegre vonatkozó kutatásokat is megkezdte. Ennek publikálására azonban csak a második világháború után (1947-ben) került sor. Tarcsaynak köszönhetjük, hogy nyoma maradt a háború elôtti tesztgyakorlatnak, és átmentette a Rorschach-tudást is a háború utáni nemzedék számára.

A nyomasztóan súlyosbodó fasizálódás, numerus clausus, egzisztenciális krízisek, a náci atrocitások növekedése a magyar szellemi elit súlyos károsítását eredményezte. Szondi 1941-ben elvesztette állami tisztségeit és címét, és emigrációra kényszerült. A fasizálódás, a munkaszolgálat, az értelmiség jelentôs részének egzisztenciális dekapitálása és a második világháború a magyar értelmiségi elitet megtizedelte, és kényszerú emigrációk sorát eredményezte. A teszt sorsa beágyazódott a pszichológia helyzetébe, ennek keretében követhetjük az 1945 utáni történéseket.

\section{A pszichológia helyzete 1945-1956 között, a szovjet pszichológia fogságában}

A „felszabadulás”-ként aposztrofált történelmi fordulat a szovjet hatalom megszállását jelentette hazánk számára. A szovjet pedológiai határozat (1936), Vigotszkij elítélése, a pedagógia hatalmának helyreállítási kísérlete magában hordozta a diszkriminatív teszthasználat és a tesztekkel végzett szakmai tevékenység elítélését, felfüggesztését. A sztálini tudománypolitikában minden tudomány erôszakhullám áldozatává vált, amint erre Pléh Csaba (1992) rámutatott. A pszichológia visszavonult védett területre, a magasabb idegmúködések vizsgálatára, a fiziológia „szolgáló lánya” lett (Pléh, 1992).

Szemben az USA-ban és Nyugat-Európában a második világháború után felfelé ívelô alkalmazott pszichológiával, nálunk szovjet mintára és parancsra a pszichológia megsemmisült mint tudomány. A „burzsoá áltudomány” címkét kapta. Megszúnt az akadémiai, egyetemi, intézményi képviselete, az itthon maradó pszichológusok belsô emigrációba vonultak.

\section{Ébredés a tetszhalálból: az alkalmazott pszichológia újjáéledése, kibontakozása, (1964-1984): a Rorschach-tesztgyakorlat virágzásának korszaka}

Az 56-os forradalom utáni konszolidáció, a Kádárkorszak „tiltás-tûrés-támogatás” rendszerének puha diktatúrája, a tudományok rehabilitációja, 1958-ban a pszichológia visszakerülése a tudományos és felsôoktatási rendszerbe, majd pedig 1963-ban az 
alkalmazott pszichológia mint önálló szak képzésének megindulása gyökeres változásokat hozott a pszichológia életébe. Szükség volt a képzésbe kerülô pszichológushallgatók gyakorlóhelyeinek kialakítására és az alkalmas tanárok kiválasztására. Ámde a kényszerú hallgatás éveiben a tanításra alkalmas pszichológusok száma megritkult, külföldön éltek, vagy megidôsödtek. A gyakorlatot képviselni tudó pszichológusok maroknyi csoportja tudta elfogadni a felkérést a gyakorlatvezetésre. Kiderült, hogy elsôsorban azok bizonyultak alkalmasnak, akik egykor Szondi laboratóriumában képzôdtek, dolgoztak.

Mérei Ferenc, aki egyetemi tanárként 1956-os politikai priusza miatt nem taníthatott, ugyanakkor éppen 1964-ben alapított az Országos Ideg- és Elmegyógyintézetben (OIE-ben) Pszichodiagnosztikai Laboratóriumot, elsôként került felkérésre a trifurkációs képzési rendszerben az 1965-tôl kötelezó gyakorlatra irányított pszichológusjelöltek gyakorlatvezetésére. Az OIE ekkor sajátos menedékhelye volt a nehéz politikai múltú, kiváló szakembereknek, így Szakács Ferencnek is, aki errôl a korszakról, melyet Mérei a klinikai pszichológia honfoglalásaként aposztrofált, személyes emlékezésében ad hiteles képet. Az életmúdíj átadásának ünnepségén mondott megemlékezésében elmondja, miképpen kezdték meg Szegedi Márton, Hajtmann Pál, Hegedús Imre, Somogyi Tóth Zsuzsanna és Gyurkovics Tibor pszichológusok a felkészülést a praxisba bevezetésre (Szakács, 2019). Ennek keretében - nagyrészt a Tarcsay-tankönyv felhasználásával - Binét Ágnes, Nemes Lívia és Mérei Ferenc közös munkával szabványosították a Rorschach-tesztet és sok egyéb gyakorlati követelmény meghatározása nyomán kialakították a tesztismereti alapokat. Tankönyv nem lévén, a hallgatók jegyzeteket készítettek, a legépelt és lerajzolt anyagokból stencilezett másolatokat, ezeket kvázi szamizdatként (a pszichológusok számára az egyetemen is közkincsként) terjedô kéziratok formájában használták tankönyvként. 1966-ban már megindult a házilagosan nyomtatott Vademecum sorozat, a Rorschach öt kötete évenként vitte tovább a hallgatókat a tesztgyakorlati tudásban. A hetvenes évekre valamennyi képesség, intelligenciateszt (standardizált MAWI és egyéb vizsgálatok), gyermek- és felnôtt-tesztek, projektív személyiségvizsgálatok (TAT, Szondi, Rorschach) hazai adaptációban, alkalmazásra fejlesztett formában rendelkezésre álltak. A rendeleti szabályozások kivívásával a „szakma" megszületett, a 38/1977 Eük. Eüm sz. rendelet elhelyezte a pszichológiai tevékenységet a humán segítô szakmák rendszerében. Errôl részletesebb ismertetést olvashatunk Szakács Ferenc megemlékezésében (Szakács, 2019).

Belátható, hogy a Rorschach-teszt fejlesztése beágyazódott a szakmai szolgálatra felkészülés tágabb volumenú munkájába. Miközben a Lipóton „megszületett” a klinikai pszichológia, azok a gyakorlati képzóhelyek is kialakultak, ahol a hallgatók a lipóti képzéshez hasonlatosan a Rorschach-teszt használatát megtanulhatták. A klinikai gyakorlat meglehetôsen egységessé vált. Azok a gyakorlóhelyek, amelyek a lipóti képzési renddel harmóniában dolgoztak, a vezetés tekintetében szinte kivétel nélkül a régi Szondi-csapat tagjai voltak. A „szondisták” csapatából Liebermann Lucy, az 1. számú gyermekklinika vezető pszichológusa, Popper Péter és Varga Zoltán pszichológusok bevonásával teremtett gyakorlóhelyet. Popper M. Vázsonyi Ibolya pszichológus tanítványának vallotta magát, és elôsegítette Vázsonyi hagyatékából a Rorschach szakanyagának kiadatását (M. Vázsonyi, 1985). György Júlia fôorvos egyrészt a Gyógypedagógia Tanárképzô Fôiskolán, másrészt a Madarász utcai kórház „Faludi utcai” gyermek- 
pszichológiai rendelôjében biztosított gyermekklinikai gyakorlatot. Binét Ágnes gyermekpszichológus, Nemes Lívia pszichoanalitikus, valamint Gerô Zsuzsa pszichológus adjunktus kiváló rorschachozóként taníthatták a tesztfelvételt és az elemzést, valamint a pszichoanalitikus gyermek-szülố terápiát is. Kozmutza Flóra még néhány éven át az egyetemi képzésben vállalta a gyógypedagógia tárgy tanítását, az intézetben pedig biztosította a vizsgálat végzésének praxisát.

Különös arculatot képez a hazai Rorschach-kultúrában a Levendel László tüdôgyógyász fốorvos Budakeszi Tüdógyógyintézetében kialakult csapatmunka, amely Mezei Ârpád pszichológus köré csoportosult. A jelen kötetben olvasható magyar nyelvú Rorschachról szóló szakirodalom-gyújteményében látható, hogy a hatvanas-hetvenes éveknek egy rövid és intenzív korszakában, a Rorschach újjászületésének idején ez a munkacsoport intenzíven dolgozott, de nem kapcsolódott be a gyakorlóhelyek közti érverésbe, noha magas színvonalú tevékenység jellemezte (lásd Mezei Árpád, Erdély Éva, Levendel László munkáit). A testvázlat tárgyában, a pszichoszomatika terén, a testi betegséggé forduló lelki zavarok témájában, valamint a Rorschach felszólító jellegekre vonatkozóan ez a csoport különösen értékes munkát prezentált a publikációiban, noha nem integrálódott a képzésbe, és eredményeik kívül maradtak a gyakorlat számára felhasználhatóvá fordítható ismereteken. Mégis, tanulmányaik, fôként Mezei Árpád és Erdély Éva munkái hozzájárultak a hazai fejlôdéshez, a teszt megismertetéséhez és presztízsének megalapozásához. Ez idóben Marton Magda is foglalkozott a Rorschach-teszttel. (Bagdy Emôke ôrzi Marton Magda Rorschach-tesztértelmezését, amelyet férjérôl, dr. Császár Gyuláról készített 1954-ben, amikor a Közegészségügyi és Járványügyi Intézetben levegótisztasági kísérleteket végzett szakmai menedékként.) Marton Lajosné, azaz Marton Magda Mendelényi Margittal közös tanulmányban foglalkozott szívneurotikus gyermekek személyiségvizsgálatával (Mendelényi és Marton, 1963).

A Rorschach-gyakorlat kialakulásában 1964-1984 között jelentôs szerepet kaptak az elkészülố tesztfejlesztô doktori disszertációk, a skálamódszereket kidolgozó tanulmányok, a megjelenô tankönyvek, mindenekelôtt Mérei Ferenc és Szakács Ferenc szakmai tevékenységet összegzô alapkönyvei: A klinikai pszichodiagnosztikai módszerek (1974a) és A klinikai pszichológia gyakorlata (1974b).

Ebben az évtizedben kezdôdött meg a nagy volumenú matematikai statisztikai (alkalmazott ági) kutatómunka is a Rorschach-teszttel, amelynek nyomán elkészült az elsố magyar standard (MARS) Vargha András matematikus-pszichológus vezetésével, valamint számos tanulmány fémjelzi a tesztfejlesztés eredményeit (Vargha, 1989a, $1989 b)$.

A Rorschach-teszt továbbfejlesztése: a közös Rorschach-vizsgálat kimunkálása és bevezetése (a nyolcvanas évektôl napjainkig)

A nyolcvanas években, a családterápiák virágzásának korszakában egyre sürgetôbbé vált az olyan tesztek bevezetése, adaptálása, standardizálása vagy a meglévôk fejlesztése, amelyek alkalmasak a kapcsolati dinamika változásainak mérésére, követésére. A debreceni pszichológusképzésben Bagdy Emôke tanszékvezetô pszichológus kezdett kísérletezni érdeklődô tanártársakból és hallgatókból álló múhelycsoportban a Jürg Willi 
svájci családterapeuta által kidolgozott páros Rorschach-módszerrel. A „Lipóti” klinikai múhellyel párhuzamosan tesztfelvételeket készítettek, a svájci kódrendszert tanulmányozták és Ruskó György hallgató szakdolgozati munkájában „tesztelte” a módszer hazai alkalmazhatóságát (Ruskó, 1987, 2002). Ennek során kiderültek az adaptációs nehézségek, és szükségesnek látszott egy új, alkalmasabb kódrendszer kimunkálása. Megkezdődött az új kódrendszer kialakítása és validálása. 1988-ban Bagdy Emốke svájci tanulmányútján bemutatta Jürg Willinek a magyar adaptációt, a fejlesztést. Willi védnökséget vállalt a munka fölött. Az egyetemi kutatómunkában, múhelymunkák és szakdolgozatok sorában születtek újabb és újabb vizsgálati eredmények. (Az e kötetben közölt Rorschach-bibliográfiában nem tüntettük fel az idegen nyelvú kongreszszusi elôadásokat, noha tíz alkalommal került sor a nemzetközi bemutatkozásra.) Elsố jelentôs munkaként a Párkapcsolatok dinamikája (2002) címú könyv számolt be a hazai standardról, a klinikai csoportok Közös Rorschach Vizsgálati (KRV) eredményeirôl és a teszt terápiakövetési, továbbá múvészeti, irodalmi múelemzési alkalmazhatóságáról. Késôbb az Egyén-pár-család (2008) címú kötetben ismertették a szerzók tesztdiagnosztikai fejlesztô munkáik eredményeit, többek között a KRV fejlesztéseket is. Bagdy és munkatársai a Károli Gáspár Református Egyetem Pszichológiai Intézetének kutatási fó profilja, a pár és családi kapcsolatok vizsgálata keretében számos fontos, a nemzetközi gyakorlatban alapvetô kapcsolati, családvizsgálati tesztet adaptálva (pl. Olson családteszt) a KRV fejlesztését is folytatták. Digitális tankönyvként adták közzé eredményeiket, az online közvetlen hozzáférhetôség biztosítása érdekében (Bagdy, Baktay és Mirnics, 2006). A fejlesztés során kialakított számítógépes értékelési változat (Bagdy, Vargha, Bánsági, 2006) használatát is belefoglalva a teszt tanításába, 2012-ig a KRV kurzusként alkotta az egyetemi képzés részét. A hallgatók mind az egyéni, mind a közös Rorschach-teszt használatára felkészültek az egyetemi képzés kereteiben. Jelen kötet processzometriát bemutató tanulmánya ízelítô a KRV használatának értékeirôl a kapcsolat diagnosztikában és a -terápiában egyaránt.

\section{A Rorschach-próba jelene}

A magyar klinikai pszichológiai gyakorlat a Mérei-szisztémának a képzésekbe és szakképzésbe beépítésével az alapvetô klinikai vizsgálati protokoll részeként alkalmazza az egyéni vizsgálatot a szaktevékenységben. Tanítása, tanulása minden pszichológusképzésben szerepel, noha eltérô súllyal és jelentôséggel. A Közös Rorschach tanítása nem általános. A klinikai alkalmazásban az utóbbi évek legértékesebb és leghasznosabb munkája Csigó Katalin (2018) klinikai szakpszichológus pszichoterapeuta, egyetemi szakképzó tanár könyve a Rorschach-teszt klinikai alkalmazásáról. Az a finommíves klinikai elemzés, amely pszichometrikusan is igényes, híven tükrözi a Rorschach-teszt klinikai alkalmazásának nívómércéjét. A teszt ilyen minôségú feldolgozására mindaddig szükségünk lesz, amíg a teszt információs repertoárjából a terápiás szempontokra és a személyiség fejlôdési, valamint állapotdinamikájára szeretnénk rálátni, megfelelô, egyénre tervezett pszichoterápiás segítségnyújtás céljából. Ha ez az igény kihal, a teszt is elveszítheti jelentôségét. 
Áttekintés a publikációkban tükröződô aktivitás és fejlődés arculatáról

Amikor elhatároztuk, hogy a magyar Rorschach-irodalmat összegyújtjük, az volt a célunk, hogy idôrendben láthatóvá tegyük a publikációs aktivitásban kifejezésre jutó szakmai megbecsülést, a fontosság és érték kifejezôdését. A hazai bibliográfiát áttekintve aktivitási korszakokat tudunk elkülöníteni. Táblázatos formában az alábbiakban szemléltetjük a publikációs aktivitásban kifejezésre jutó értéktükrözôdést. Ebben a fejlôdésben öt szakasz látszik jól elkülöníthetônek, melyet az 1. táblázaton láttatunk.

1. táblázat. Publikációk száma történeti korszakonként

\begin{tabular}{|c|c|c|c|c|c|c|c|}
\hline \multirow{3}{*}{$\begin{array}{l}\text { Korszakok } \\
\text { 1940-1959 } \\
\text { „Tetszhalál” }\end{array}$} & \multirow{3}{*}{\begin{tabular}{|c|} 
Könyvek \\
3 \\
kettó \\
idegen \\
nyelven \\
\end{tabular}} & \multirow{3}{*}{$\begin{array}{c}\begin{array}{c}\text { Könyv- } \\
\text { fejezetek }\end{array} \\
6\end{array}$} & \multirow{3}{*}{$\begin{array}{c}\begin{array}{c}\text { Folyóirat- } \\
\text { tanulmá- } \\
\text { nyok }\end{array} \\
\\
2\end{array}$} & \multirow{3}{*}{\begin{tabular}{|c|}
$\begin{array}{c}\text { Doktori } \\
\text { értekezések }\end{array}$ \\
- \\
\end{tabular}} & \multirow{3}{*}{$\begin{array}{c}\begin{array}{c}\text { Szak- } \\
\text { dolgozatok }\end{array} \\
-\end{array}$} & \multicolumn{2}{|c|}{ Szakképzések } \\
\hline & & & & & & $\begin{array}{l}\text { Fel- } \\
\text { nôtt }\end{array}$ & $\begin{array}{l}\text { Gyer- } \\
\text { mek }\end{array}$ \\
\hline & & & & & & - & - \\
\hline $\begin{array}{l}\text { 1960-79 } \\
\text { Újjászületés }\end{array}$ & 17 & 25 & 14 & 4 & - & - & - \\
\hline $\begin{array}{l}1980-99 \\
\text { Kiegyenlítôdés }\end{array}$ & 17 & 16 & 9 & 4 & 19 & 390 & 259 \\
\hline $\begin{array}{l}2000-2009 \\
\text { A közös } \\
\text { Rorschach-éra }\end{array}$ & 11 & 63 & 17 & 7 & 88 & 311 & 245 \\
\hline $\begin{array}{l}\text { 2010-2019 } \\
\text { A változás } \\
\text { évtizede }\end{array}$ & 5 & 4 & 3 & - & 51 & 443 & 408 \\
\hline $\begin{array}{l}\text { Összesen } \\
80 \text { év alatt }\end{array}$ & 53 & 115 & 45 & 15 & 158 & 1144 & 912 \\
\hline
\end{tabular}

A táblázatból jól követhetôk a Rorschach hazai útjának korszakai. A kezdetben két-két, majd egy-egy évtizedet szakaszoló idô öt arculatos idôzónát rajzol ki.

1940 és 59 közé esik az elsô idôsáv. Ez magába foglalja a második világháború utáni, jobbára mégis az 1945-ös szovjet megszállást követô szakmai „tetszhalál” idejét, amelyben „hallgattak a múzsák”, gyér publikációs aktivitás látszik. Húsz év alatt mindössze három könyv jelent meg, abból kettố magyar szerzổ külföldön megjelentetett múve. A teszthasználatra tilalom vonatkozott. Hat tanulmány mégis napvilágot láthatott. Gegesi Kiss Pál professzor szerkesztésében a Pszichológiai Tanulmányok kötetei tûrték meg a Rorschachhal kapcsolatos írásokat (például Mezei és Mezeiné, 1962, 1965).

A második korszak (1960-1979) az újjászületés ideje, a klinikumban ez a Mérei által „honfoglalásnak” nevezett idôszak. A teszt „ébredése” része a hazai pszichológia önmagára találásának. Ez idôszak alatt minden olyan alapkönyv és tankönyv megjelent, országosan elterjedt és használatba vételre került, amely a Rorschach magas szintú alkalmazását lehetôvé tette, és megalapozta a magyar teszthasználat Mérei és munkatársai által kidolgozott jelölési, értelmezési rendszerét. Mérei Ferenc és Szakács Ferenc e korszak vezérlő csillagai. Bôséges információval szolgál minderrôl Szakács Ferenc, aki 
az életmúdíj-átvételekor mondott beszédében e korszak jelentôségérôl emlékezik meg (Szakács F. 2019, kézirat, megjelenés alatt).

A harmadik korszak a nyolcvanas-kilencvenes évekre tehetô (1980-1999). A publikációs aktivitásban az egyensúly, a könyvek magas száma, a MARS (Magyar Rorschach Standard) által biztosított pszichometriai követelmények teljesítése, a tanulmányokban is az igényesség tükrözôdik. A szakdolgozati aktivitás megindult, ami az egyetemi tanulmányokba foglalt teszttanulást juttatja kifejezésre. A könyvek száma a teszt presztízsnövekedését is kifejezi.

Az ezredfordulótól új éra veszi kezdetét. A hazai családterápiás fellendüléshez kapcsolódó kutatásokban a pár- és családdinamikai irányvételnek megfelelôen a mérôeszközök iránt is megnövekedett a szükséglet. A Közös Rorschach Vizsgálat (KRV) üstökösként tört be a pszichodiagnosztikába. A debreceni pszichológusképzésben, majd pedig 2000-tôl a Károli Gáspár Református Egyetem Pszichológia szakán folyó kutatások részeként Bagdy Emôke vezette be az új jelölô és értékelő eljárást, amelyhez rendkívül sok szakdolgozati munka (még több, az e kötetben fellelhetô Rorschach-bibliográfiában nem jelzett egyetemi múhelymunka) csatlakozott. A kimagasló publikációs aktivitás jól jelzi, hogy a debreceni KLTE-n induló, majd a KRE-n folytatódó kutatások szellemi hozama a csúcsra került, alkalmazási gyakorlata pedig a hallgatók teszttanulásának szerves részévé vált. A Közös Rorschach interaktometriai és processzometriai rendszere gazdagítólag hatott a Rorschach-gyakorlatra.

Az ötödik szakasz elsô évtizedét most töltjük meg szellemi és gyakorlati tartalommal. 2010 és 2019 között szemmel látható visszaesést tükröz a publikációs aktivitás. Doktori munka nem született, a szakdolgozati aktivitás még tartja magát, remélhetôleg nem apad le jelentôsen. A könyvek, könyvfejezetek és tanulmányok száma szignifikánsan megcsappant. A klinikumban Csigó Katalin monográfiája emelkedik ki a szakkönyvek sorából. A Rorschach-próba nemzetközi helyzetének ismeretében válságról is szólhatunk.

A teszthez való viszonyt a képzésben elfoglalt helye és annak mértéke is jól tükrözi. Az egyetemi autonómia értelmében a képzô intézmények saját felelôsséggel adnak súlyt, jelentôséget a projektív vizsgálatoknak. A klinikai szakképzésben egyelôre még követelmény a használata, a klinikai protokoll része. Az alapképzésben már nagy különbségek láthatók. A nemzetközi trendet tekintetbe véve a jövốt feltehetôen és sajnálatosan olyan Rorschach jelenti majd, amely a mai munkakövetelményeknek megfelel: rövid, gyors, a klinikumban digitális igen-nem válaszokkal ad információt, amelyet szakági hovatartozástól függetlenül minden pszichológus alkalmazhat, amelynek számítógépes, nyomtatott eredményeihez egyszerú a hozzájutás, és a teszt objektivitása, validitása, megbízhatósága magas. Ezt a trendet látjuk a R-PAS fejlesztésben is, amellyel külön tanulmányban ismerkedhetünk meg.

\section{IRODALOM}

Bagdy E. (1992). „Majd eljön értem a halott”. József Attila befejezetlen személyiségvizsgálatáról. In Horváth I., Tverdota Gy. (szerk.), Miért fáj ma is? Budapest: Balassi Kiadó. 65-115.

Bagdy E. (szerk.) (2002). Párkapcsolatok dinamikája. Interakciódinamikai vizsgálatok a Közös Rorschach teszttel. Budapest: Animula Kiadó. 
Bagdy E., Baktay Z. \& Mirnics Zs. (szerk.) (2008). Pár és családi kapcsolatok vizsgálata. Digitális tankönyv. Letöltve: 2019. 10. 25-én: http://webcreator.hu/tankonyv.

Bagdy E., Mirnics Zs., \& Vargha A. (szerk.) (2007). Egyén, pár, család: tanulmányok a pszichodiagnosztikai tesztadaptációs és tesztfejlesztési kutatások köréból. Budapest: Animula Kiadó. 75-87.

Bagdy E., Vetier A., Csákvári Zs., Kiss D. R., Vargha A., Bánsági P. (2006). Processzometria: interakciós folyamelemzô eljárás a Közös Rorschach próbában. In: Bagdy E., Baktay Z. \& Mirnics Zs. (szerk.) (2008). Pár és családi kapcsolatok vizsgálata. Digitális tankönyv.

Bürgi-Meyer K. (1996). A laboratórium egy lázasan dolgozó hangyatársadalom. Thalassa, 7(2), 83-103.

Csigó K. (2018). A Rorschach-teszt klinikai alkalmazása. Budapest: Medicina Kiadó.

Garai L. (1992). „Amit meglátok hirtelen”. In Horváth I., Tverdota Gy. (szerk.), Miért fáj ma is? (pp. 117-145). Budapest: Balassi Kiadó.

Illyés Gyné. (1987). József Attila utolsó hónapjairól. Budapest: Szépirodalmi Könyvkiadó.

K. Horváth Zs. (2011). Kívül. Peremhelyzet és habitus formálódása Mérei Ferenc élettörténetében. Doktori disszertáció. 2011. június 29. MTA Könyvtára.

Mendelényi M., \& Marton L. (1963). Szívneurotikus gyermekek személyiségvizsgálata a klinikum és a Rorschach próba alapján. In Gegesi Kiss P. (szerk.), Pszichológiai tanulmányok V. (pp. 485-500). Budapest: Akadémiai Kiadó.

Mérei F. (1947). A Rorschach táblák felszólító jellege. Magyar Pszichológiai Szemle, 16(3-4), 115-125.

Mérei F., \& Szakács F. (1974a). Klinikai pszichodiagnosztikai módszerek. Budapest: Medicina Kiadó.

Mérei F., \& Szakács F. (1974b). A klinikai pszichológia gyakorlata. Budapest: Medicina Kiadó.

Mezei Á., \& Mezeiné Erdély É. (1962). A Rorschach táblák felszólító jellegének vizsgálata. In Gegesi Kiss P. (szerk.), Pszichológiai Tanulmányok IV. (pp. 615-622). Budapest: Akadémiai Kiadó.

Mezei Á., \& Mezeiné Erdély É. (1965). Újabb személyiségdimenziók a Rorschach próbában. In Gegesi Kiss P. (szerk.), Pszichológiai Tanulmányok VIII. (pp. 609-620). Budapest: Akadémiai Kiadó.

M. Vázsonyi I. (1985). Rorschach szótár. A Rorschach teszt gyakorlati kézikönyve. Budapest: Magyar Pszichológiai Társaság.

Noszlopi L. (1989). Sorselemzés és ösztöndiagnosztika. A Szondi-féle ösztönlélektan teljes ismertetése. Budapest: Akadémiai Kiadó.

Pléh Cs. (1992). Pszichológiatörténet. Budapest: Gondolat Kiadó.

Ruskó Gy. (1987): Családdinamikai elemzés lehetôségei „Közös Rorschach Vizsgálattal”. Szakdolgozat, ELTE, Budapest.

Ruskó Gy. (2002). A KRV alkalmazásának kezdeti tapasztalatai magyar családoknál. In Bagdy E. (szerk.), Párkapcsolatok dinamikája. Interakciódinamikai vizsgálatok a Közös Rorschach teszttel (pp. 88-96). Budapest: Animula Kiadó.

Szakács F. (2010). November 100. Szubjektív emlékezés Mérei Ferencre. Magyar Pszichológiai Szemle, 65(2), 343-350.

Szakács F. (2019). Mérei Ferenc és a hazai klinikai pszichológia sztenderdjei. In Pléh Cs., Mészáros J., Csépe V. (szerk.), A Pszichológiatörténet-írás módszerei és a magyar pszichológiatörténet (pp. 395-340). Budapest: Gondolat Kiadó.

Tarcsay I. (1940). Pszichodiagnosztika, a Rorschach vizsgálat és klinikai alkalmazása. Budapest: Eggenberger-féle Könyvkereskedés.

Vargha A. (1989a). A magyar Rorschach standard táblázatai. Egységes jegyzet. Budapest: Tankönyvkiadó.

Vargha A. (1989b). A nem, az életkor, az iskolázottság és a diagnózis hatása az egyes Rorschach-jegyekre: egy átfogó empirikus Rorschach vizsgálat eredményei. Egységes jegyzet. Budapest: Tankönyvkiadó. 


\section{THE HUNGARIAN PATH OF THE RORSCHACH TEST}

\section{CSÁSZÁR-NAGY, NOÉMI}

Objective: This study aims to trace the establishment, spread and application of the Rorschach projective personality examination, mainly in clinical fields. To date, there has been no systematic and scientific examination of the history of the test within the framework of the development of Hungarian applied psychology, which the present study aims to redress.

Method: This study is based on an analysis of historical sources and data on the development of the application of the Rorschach test, as well as a chronological examination of relevant publications. The development process can be divided into five stages. The most significant developmental leaps were the introduction of and training for the Joint Rorschach test and the introduction of the R-PAS, an empirically based scoring system for the Rorschach test, in the framework of the international Rorschach renewal.

Results: The study highlights the importance of the Szondi School in the introduction and establishment of the Rorschach test in Hungary, and the role of Ferenc Mérei and Ferenc Szakács in Hungarian clinical psychological practice, as well as that of Emóke Bagdy in the Hungarian application of the Joint Rorschach.

Conclusion: The study shows that the test has been given a new lease of life, in line with the latest methodology and the effects of changing approaches to psychological practice. At the same time, the testing requirements (validity, reliability, renewal of standards, etc.) are constant across time.

Keywords: Rorschach test, Joint Rorschach Test (JRT), test history data

A cikk a Creative Commons Attribution 4.0 International License (https://creativecommons. org/licenses/by/4.0) feltételei szerint publikált Open Access közlemény, melynek szellemében a cikk bármilyen médiumban szabadon felhasználható, megosztható és újraközölhetô, feltéve, hogy az eredeti szerzô és a közlés helye, illetve a CC License linkje és az esetlegesen végrehajtott módosítások feltüntetésre kerülnek. (SID_1) 